\title{
A Revogação dos Artigos 46 e 48, do Código de Contabilıdade Pública e suas Conseqüências
}

\author{
Oscar Victorino MOREIRA \\ lécnico de Administração
}

A mento de vencimentos do funcionalismo público federal, que será lei especial, entretanto, alguns dispostivos vêm sendo agregados, embora constituam matéria estranha ao projeto. Não nos move propósito de criticar o processo adotado, mas o de alertar os res ponsáveis pela direção do País, principalmente quanto aos efeitos práticos das emendas apresentadas ao projeto. Limitamo-nos à apreciação do que concerne à proposição da revogação dos artigos 46 e 48, do Código de Contabilidade Pública. A fim de esclarecer, valerá transcrever os citados artigos ei-los:

"Art. 46. O empenho da despesa não poderá exceder às quantias fixadas pelo Congresso Nacional (exceto nos casos de pensões, vencimentos e porcentagens marcados em lei, ajudas de custo, comunicações ou transportes necessários aos serviços públicos).

Art. 48. Os chefes de repartições que ordenarem fornecimento ou prestação de serviços de custo excedente às quantias prèviamente fixadas pelo Congresso Nacional, ficarão sujeitos às penalidades do art. 40, im postas pelo Tribunal de Contas, por ocasião do exame das dividas relacionadas.

$\S 1$. No caso de necessidade impreterivel, deverão solicitar autorização escrita do Ministro competente, que dará, se julgar conveniente nos mesmos papéis de que constarem a insuficiência dos créditos e a razão da despesa".

Muitas são as vozes que se têm levantando contra a constitucionalidade de tais dispositivos e, dentre elas, algumas no Tribunal de Contas. Estamos propensos a acreditar que a tal inconstitucionalidade não deva ser assim, tão flagrante, ou que o próprio Tribunal tenha evoluido em sua forma de interpretar, pois temos em mãos um volume do "Parecer Prévio Sôbre as Contas 
do Presidente da República" - 1958, elaborado pelo Ministro VIDal da Fontoura e aprovado pelo Egrégio Tribunal. O trabalho foi impresso no Departamento de Imprensa Nacional, em 1960.

À página 58, o Relator aponta as criticas feitas à constitucionalidade dos dispositivos em causa, mas à página 56 , relaciona as - despesas realizadas sem crédito e as além dos créditos, pelos diversos órgãos da administração pública, graças ao emprêgo daquele dispositivo legal. Embora diga que os artigos 46 e 48 , do Código de Contabilidade Pública se chocam com o disposto no art. 77 , $\S 3$, da Constituição, o próprio Tribunal de Contas aparece na relação dos órgãos que realizaram despesas além dos créditos, na importância de $\operatorname{Cr} \$ 23.198 .498,90$.

Acreditamos que tenham guardado a maior conformidade com os mandamentos do Código, mas o próprio Tribunal aparece na relação, é curioso e só pode provar que êle mesmo não julga tal procedimento ofensivo à Magna Carta .

Estamos alertando a administração pública para êste fato, porque constantemente verificamos proposições no sentido da revogação daqueles dispostivos sem serem substituidos por outros que permitam a administração trabalhar.

Imaginemos a impossibilidade da prática dos atos permitidos por aquêles dispositivos. Ao terminar o exercício financeiro, findos os recursos orçamentários, deixar-se-ia de pagar: - pensões, vencimentos, gratificações, assim como adquirir e pagar alimentação para hospitais, prisões, escolas, além de cumbustiveis e lubrificantes, já não falando no cancelamento de viagens, iluminação de repartições, etc.

Não é possivel desarmar-se a administração desta válvula, sem propiciar-se o estabelecimento do caos, a revolta, a subversão da ordem pública. Se os pensionistas não receberem o pouco a que têm direito, os enfermos ficarem sem alimentação e medicamentos, a policia não puder deslocar-se por falta de combustivel, ocorrerá a paralização dos serviços públicos inopinadamente, porque a administração foi privada do recurso legal.

Atente-se para êste ponto: - a supressão daqueles artigos 46 e 48 só atingiriam a administração direta, pois a autárquica e as sociedades de economia mixta não seriam afetadas. Será que só a administração direta é que precisa ser emperrada, limitada em sua ação, tornando-se ineficiente? Uma das razões da criação das entidades paraestatais é justamente fugir a êste estado de coisas. Bem sabemos que o Tribunal de Contas é um dos que mais fulmina aquelas disposições do Código, embora, como lemos em seu "Parecer Prévio", acima citado, êle próprio se valeu, 
quando se viu forçado. Não é de admirar que o Tribunal declare em seus pareceres prévios que só $14 \%$ das despesas públicas estão sujeitas ao "registro prévio". E' o mais natural, que cada um de nós procure, quando pode, fugir a um regime cheio de impecilhos, sem a menor utilidade, já que outros regimes existem que permitem ao administrador trabalhar.

Antes que o mal ocorra, é conveniente alertar e sugerir a não aprovação da emenda e se esta fôr aprovada, será o caso da aplicação do veto, na defesa da administração. Devemos estar prevenidos contra novas tentativas, partindo mesmo de quem, em certas ocasiões, usa o recurso, embora condene sua prática por outrem. 